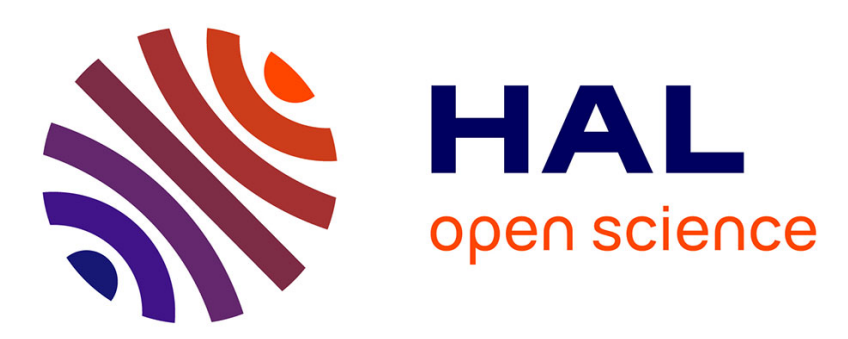

\title{
Tests for the Use of La2Mo2O9-based Oxides as Multipurpose SOFC Core Materials
}

Julien Jacquens, D. Farrusseng, Samuel Georges, Jean-Paul Viricelle, Cyril Gaudillère, Corbel Gwenaël, Philippe Lacorre

\section{To cite this version:}

Julien Jacquens, D. Farrusseng, Samuel Georges, Jean-Paul Viricelle, Cyril Gaudillère, et al.. Tests for the Use of La2Mo2O9-based Oxides as Multipurpose SOFC Core Materials. Fuel Cells, 2010, 10 (3), pp.433-439. 10.1002/fuce.200900099 . emse-00491180

\section{HAL Id: emse-00491180 \\ https://hal-emse.ccsd.cnrs.fr/emse-00491180}

Submitted on 21 Sep 2010

HAL is a multi-disciplinary open access archive for the deposit and dissemination of scientific research documents, whether they are published or not. The documents may come from teaching and research institutions in France or abroad, or from public or private research centers.
L'archive ouverte pluridisciplinaire HAL, est destinée au dépôt et à la diffusion de documents scientifiques de niveau recherche, publiés ou non, émanant des établissements d'enseignement et de recherche français ou étrangers, des laboratoires publics ou privés. 


\title{
Tests for the Use of $\mathrm{La}_{2} \mathrm{Mo}_{2} \mathrm{O}_{9}$-based Oxides as Multipurpose SOFC Core Materials
}

\section{Julien J ACQUENS ${ }^{(1)}$ ， DAVId FARRUSSENG( ${ }^{(2)}$, SAMUEL GeORGeS(3), J EAN-PAUL Viricelle ${ }^{(4)}$, CYril GAUdillère(2),(5), GWENAËL CORBEL ${ }^{(1)}$, PHILIPPE LACORRE ${ }^{(1)} *$}

(1) Laboratoire des Oxydes et Fluorures, UMR CNRS 6010, Université du Maine, Avenue Olivier Messiaen, 72085 Le Mans cedex 9, France

(2) IRCELYON, Institut de Recherches sur la Catalyse et l'Environnement de Lyon, UMR CNRS 5256, Université Lyon 1, CNRS, 2 avenue Albert Einstein, 69626 Villeurbanne, France

(3) Laboratoire d'Electrochimie et de Physico-chimie des Matériaux et des Interfaces, UMR CNRS 5631-INPG-UJ F, BP 75, 38402 Saint Martin d'Hères cedex, France

(4) Ecole Nationale Supérieure des Mines de Saint Etienne, Centre SPIN ; Département MICC ; LPMG -UMR CNRS 5148, 158 Cours Fauriel ; 42023 Saint-Étienne Cedex 2, France

(5) Institut Carnot de Bourgogne, UMR CNRS 5209, 9 Avenue Alain Savary, BP 47870, 21078 Dijon cedex, France

\begin{abstract}
The mixed ionic-electronic conductivity under dilute hydrogen, the stability and the catalytic activity under propane:air type mixtures of a series of LAMOX oxide-ion conductors have been studied. The effect of exposure to dilute hydrogen on the conductivity of the $\beta$ - $\mathrm{La}_{2}\left(\mathrm{Mo}_{2}\right.$. ${ }_{\mathrm{y}} \mathrm{W}_{\mathrm{y}} \mathrm{O}_{9}$ series at $600{ }^{\circ} \mathrm{C}$ depends on tungsten content: almost negligible for the highest $(\mathrm{y}=1.4)$, it is important for $\mathrm{La}_{2} \mathrm{Mo}_{2} \mathrm{O}_{9}(\mathrm{y}=0)$. In propane:air, all tested LAMOX electrolytes are stable at $600-700{ }^{\circ} \mathrm{C}$, but get reduced when water vapour is present. $\mathrm{La}_{2} \mathrm{Mo}_{2} \mathrm{O}_{9}$ is the best oxidation catalyst of the series, with an activity comparable to that of nickel.The catalytic activity of other tested LAMOX compounds is much lower, $\left(\mathrm{La}_{1.9} \mathrm{Y}_{0.1}\right) \mathrm{Mo}_{2} \mathrm{O}_{9}$ showing a deactivation phenomenon. These results suggest that depending on composition, $\mathrm{La}_{2}\left(\mathrm{Mo}_{2}\right.$ y $\mathrm{W}_{\mathrm{y}} \mathrm{O}_{9}$ compounds could be either electrolytes in single-chamber SOFC and dual-chamber micro-SOFC ( $\mathrm{y}=1.4$ ) or anode materials in dual-chamber SOFC (low y) or oxidation catalysts in SOFCs operating with propane $(\mathrm{y}=0)$.
\end{abstract}

Keywords:

LAMOX ; Mixed Ionic Electronic Conduction ; Oxidation Catalysis ; Propane ; Reduction ; Single or Dual Chamber ; Solid Oxide Fuel Cell ; Stability

\section{Introduction}

The discovery, in $\mathrm{La}_{2} \mathrm{Mo}_{2} \mathrm{O}_{9}$, of an oxide-ion conductivity higher than that of stabilised zirconias above $580{ }^{\circ} \mathrm{C}$ [1] opened the prospect for using this material or its derivatives (the so-called LAMOX family [2]) as electrolyte in intermediate temperature solid oxide fuel cells (ITSOFCs). Indeed, it would lower the cell working temperature by about $150{ }^{\circ} \mathrm{C}$ in comparison to the standard 8 mol.-\%YSZ. However, the drawback of molybdates as electrolytes in conventional SOFC devices is their tendency to easily get reduced in hydrogen. It is for instance the case of Y substituted LAMOX which, when reduced, show additional

\footnotetext{
* Auteur à qui la correspondance devait être adressée : philippe.lacorre@univ-lemans.fr
} 
electronic conductivity due to mixed-valent molybdenum [3]. However, the reducibility of LAMOX compounds can be minimised through partial substitution of molybdenum for tungsten (up to $<75 \%$ ) [4]. A careful examination of the stability phase diagram of Wsubstituted $\mathrm{La}_{2} \mathrm{Mo}_{2} \mathrm{O}_{9}$ [5] shows that there is a region in $\mathrm{P}_{2}\left(\mathrm{O}_{2}\right)-\mathrm{T}$ where $\mathrm{La}_{2} \mathrm{Mo}_{2} \mathrm{O}_{9}$ can get reduced whereas $\mathrm{La}_{2}\left(\mathrm{Mo}_{0.5} \mathrm{~W}_{1.5}\right)_{9}$ remains stable. It opens up the way for using LAMOX compounds either as electrolyte or as anode materials, depending on SOFC configuration (conventional or single chamber) and on operating temperature. Moreover, both molybdenum and lanthanum are highly active catalytic elements in selective oxidation and oxidative dehydrogenation, and $\mathrm{La}_{2} \mathrm{Mo}_{2} \mathrm{O}_{9}$ has already been known to be a catalyst for selective oxidation of toluene [6]. Therefore, LAMOX materials might also be useful as oxidation catalysts for internal reforming at the anodic side of direct hydrocarbon SOFC devices [7].

The above considerations incited us to undertake a study on the electrical, catalytic and stability properties of a series of LAMOX compounds in hydrogen (ideal fuel for non-polluting waste) and propane (ideal hydrocarbon for its high energy density in liquid form [8, 9]) fuel gas atmospheres.

The aim was to test their ability to be used as multipurpose materials (electrolyte and/or anode and/ or catalyst, depending on composition) in such devices as single or dual chamber (be it hydrogen or direct hydrocarbon) intermediate temperature SOFCs. First results are presented here.

\section{Experimental}

\section{II.1. Samples preparation}

\section{II.1.1 Powder samples}

Reference and LAMOX powders used in this study were either commercial samples (Ni), or prepared by solid-state reaction from commercial elementary oxides. Typical thermal treatments for the preparation of LAMOX compounds include a pre-annealing for $12 \mathrm{~h}$ at $500^{\circ} \mathrm{C}$ (in order to avoid molybdenum oxide sublimation) followed by a series of annealings between 900 and $1,225{ }^{\circ} \mathrm{C}$ depending on composition, with intermediate grindings (heating/cooling rates of $5{ }^{\circ} \mathrm{C}$ min-1). At room temperature, all LAMOX compounds are obtained in their cubic $\beta$ form, except for $\mathrm{La}_{2} \mathrm{Mo}_{2} \mathrm{O}_{9}$ and $\mathrm{Pr}_{2} \mathrm{Mo}_{2} \mathrm{O}_{9}$ which are in the monoclinic $\alpha$ form.

The $\mathrm{La}_{7} \mathrm{Mo}_{7} \mathrm{O}_{30}$ sample used in the stability study under propane:air was prepared by partial reduction under dilute hydrogen of a $\mathrm{La}_{2} \mathrm{Mo}_{2} \mathrm{O}_{9}$ powder sample (see Ref. [10]): a $1 \mathrm{~g}$ sample of $\mathrm{La}_{2} \mathrm{MO}_{2} \mathrm{O}_{9}$ is annealed in a quartz crucible at $760{ }^{\circ} \mathrm{C}$ under a 6 vol.- $\% \mathrm{H}_{2}-94$ vol.- $\% \mathrm{~N}_{2}$ flowing gas mixture until weight loss reaches about $1.117 \%$, the theoretical value for $\mathrm{La}_{7} \mathrm{Mo}_{7} \mathrm{O}_{30}$ composition (usually after 3-4 h, a diffuse partial reduction plateau is reached). The heating and cooling rates in the same atmosphere were $30{ }^{\circ} \mathrm{C} \mathrm{min}-1$.

Phase purity was checked by room temperature X-ray diffraction, on a PANalytical $\mathrm{h} / \mathrm{h}$ BraggBrentano X'pert MPD PRO diffractometer ( $\mathrm{CuK} \alpha_{1+2}$ radiations) equipped with an X'celerator detector ( $2 \mathrm{~h}$ range $5-130^{\circ}$, $2 \mathrm{~h}$ step $0.0084^{\circ}$, total counting time $5 \mathrm{~h}$ ).

\section{II.1.2 Pellets}

The $\mathrm{La}_{2}\left(\mathrm{Mo}_{2}-\mathrm{y}_{\mathrm{y}}\right) \mathrm{O}_{9}$ pellet samples used for the conductivity study were prepared from the previous powder batches with the same composition. Powders were first ball-milled in a FRITSCH planetary micromill pulverizette 7 apparatus. The two agate vials containing $<900 \mathrm{mg}$ of powder each, together with six agate balls (diameter $<1.2 \mathrm{~cm}$ ) in ethanol, are rotated at 1,120 rpm for four cycles of $15 \mathrm{~min}$, with 15 min rest in between. Samples with about $300 \mathrm{mg}$ of the previous ground powder, mixed with one drop of a solution of polyvinylic alcohol as an organic binder, were then shaped as pellets in a $5 \mathrm{~mm}$ diameter mould by uniaxial pressing at $500 \mathrm{MPa}$, followed by isostatic pressing at $500 \mathrm{MPa}$. The shaped samples were heated at $400{ }^{\circ} \mathrm{C}$ for $12 \mathrm{~h}$ (heating rate $2{ }^{\circ} \mathrm{C} \mathrm{min}-1$ ) in order to decompose the organic binder, then sintered on Pt wedges for $3 \mathrm{~h}$ at $1,000{ }^{\circ} \mathrm{C}$ for $\mathrm{y}=0$, at $1,175{ }^{\circ} \mathrm{C}$ for $\mathrm{y}=0.5$ or at $1,225^{\circ} \mathrm{C}$ for $\mathrm{y}=1$ and $\mathrm{y}=1.4$ (heating rate $5^{\circ} \mathrm{C}$ min-1). The relative densities were higher than $97(1) \%$. 


\section{II.2. Conductivity measurements}

The total conductivity of the $\mathrm{La}_{2}\left(\mathrm{Mo}_{2}-\mathrm{yWy}\right) \mathrm{O}_{9}$ pellet samples at different temperatures in air, in Ar and in commercial 90\% Ar- 10\% $\mathrm{H}_{2}$ mixture (Argon MHU10, Air Liquide) at total flowrate $0.6 \mathrm{~L} \mathrm{~h}-1$, was measured by complex impedance spectroscopy in the frequency range $13 \mathrm{MHz}-$ $5 \mathrm{~Hz}$. For this purpose, a Hewlett Packard 4192A frequency response analyser was used. The measurements were performed at the open circuit voltage, and the applied AC voltage was $50 \mathrm{mV}$. Prior to measurements, thin film platinum electrodes (Pt paste) were deposited on both faces of each pellet sample. The samples were connected to the frequency response analyser using platinum grids and wires, mounted on a stainless steel triple sample holder placed inside an alumina tube, and positioned in a Pyrox furnace. The properties of the three samples were therefore investigated almost simultaneously by semi-automatic measurement. The electrical properties of the pellet samples were measured in air while heating up, then in pure argon at $608{ }^{\circ} \mathrm{C}$, then in the $\mathrm{Ar}-\mathrm{H}_{2}$ mixture for $24 \mathrm{~h}$ at the same temperature and finally during cooling down from $608{ }^{\circ} \mathrm{C}$ to $\mathrm{RT}$ in the $\mathrm{Ar}-\mathrm{H}_{2}$ atmosphere. The measurement is performed after at least 30 min of thermal stabilisation.

The sample resistance was evaluated by intercepting data with the $\operatorname{Re}(\mathrm{Z})$ axis. Occasionally, for the measurements in air, when this evaluation required the deconvolution of sample/ electrode contribution, impedance data were fitted using a R/ / CPE electrical circuit with the equivalent circuit option of the ZVIEW program (Scribner Associates Inc.).

\section{II.3. Measurements in propane:air atmospheres}

Fuel:air mixtures are typical gas environment for single-chamber SOFC devices, which rely on the difference in catalytic activities between the anode and cathode materials (for hydrocarbon oxidation and oxygen reduction, respectively) [11, 12]. Due to the relatively large explosivity domain of these fuel mixtures, special care relative to gas balance should be taken for measurements in such atmospheres. Lower and upper explosivity limits of propane volume percent in standard conditions (LEL $=2.2$ vol.- $\%$ and UEL $=10$ vol.- $\%$, respectively [13]) enable two possible working areas, which vary with temperature and pressure $[13,14]$ (see Figure 1). High nitrogen inerting, which enables to prospect any $\mathrm{C}_{3} \mathrm{H}_{8}: \mathrm{O}_{2}$ proportion, is recommended in order to avoid explosion risks.

\section{II.3.1. Thermal stability}

For stability tests of LAMOX compounds in propane:air mixture, we used a 16:84 vol.-\% propane:air proportion (above UEL), in propane excess relative to the optimal 10:90 vol.- \% proportion used in single-chamber SOFC [15, 16]. The aim was to accelerate ageing while avoiding explosivity risks. In addition, the effects of nitrogen inerting (initial mixture diluted twice in nitrogen) and of water vapour (around 2-3\%, from gas bubbling in water) were measured.

For each composition, a single batch of around $500 \mathrm{mg}$ of raw powder was placed in an alumina boat inside a tubular furnace allowing gas flowing, with variable area flowmeters controlling each gas flow. A thermal plateau with T equal to 600 or $700{ }^{\circ} \mathrm{C}$ was applied for 24- $72 \mathrm{~h}$ in the gas mixture (with heating and cooling in nitrogen at $10^{\circ} \mathrm{C} \mathrm{min}-1$ ).

After the thermal treatment, samples were characterised by X-ray diffraction (XRD). XRD patterns were recorded at room temperature on a Siemens D5000 diffractometer or on the PANalytical h/ h Bragg-Brentano X'pert MPD PRO diffractometer (Cu Ka1 + 2 radiations).

\section{II.3.2. Catalytic activity}

Catalytic tests were carried out below LEL in an oxygenrich 1.8:98.2 vol.-\% propane:'air' gas mixture in order to avoid coking. Some tests were also performed in a 2:98 vol.-\% methane:'air' gas mixture. By 'air', we mean a 20:80 vol.- \% O2:He gas mixture. Catalytic measurements were performed on a SWITCH 16 reactor System (AMTEC GmbH), which can contain up to 16 samples [17]. This system is built up from 16 tubular reactors (internal diameter $7 \mathrm{~mm}$ ) placed in a heating device and individually connected to an inlet gas valve. All the tubing and valves are heated in order to avoid water vapour condensation. Feed and outflow gases are analysed by gas chromatography (Agilent 3000 version QUAD instrument) equipped with Agilent 6890 thermal conductivity detectors (columns molecular sieve 5A, 
PoraPlot U and PoraPlot Q for $\mathrm{O}_{2}, \mathrm{CH}_{4}, \mathrm{CO}$ and $\mathrm{CO}_{2}, \mathrm{C}_{3} \mathrm{H}_{8}-\mathrm{x}, \mathrm{C}_{4} \mathrm{H}_{10}-\mathrm{x}$ measurements), and Agilent 6850 flame ionisation detectors (columns OV1 and Stabilwax for carboxylic acids and aldehydes measurements). The major part of water contained in the gas mixture is condensed upstream before the modules with a Peltier cooler.

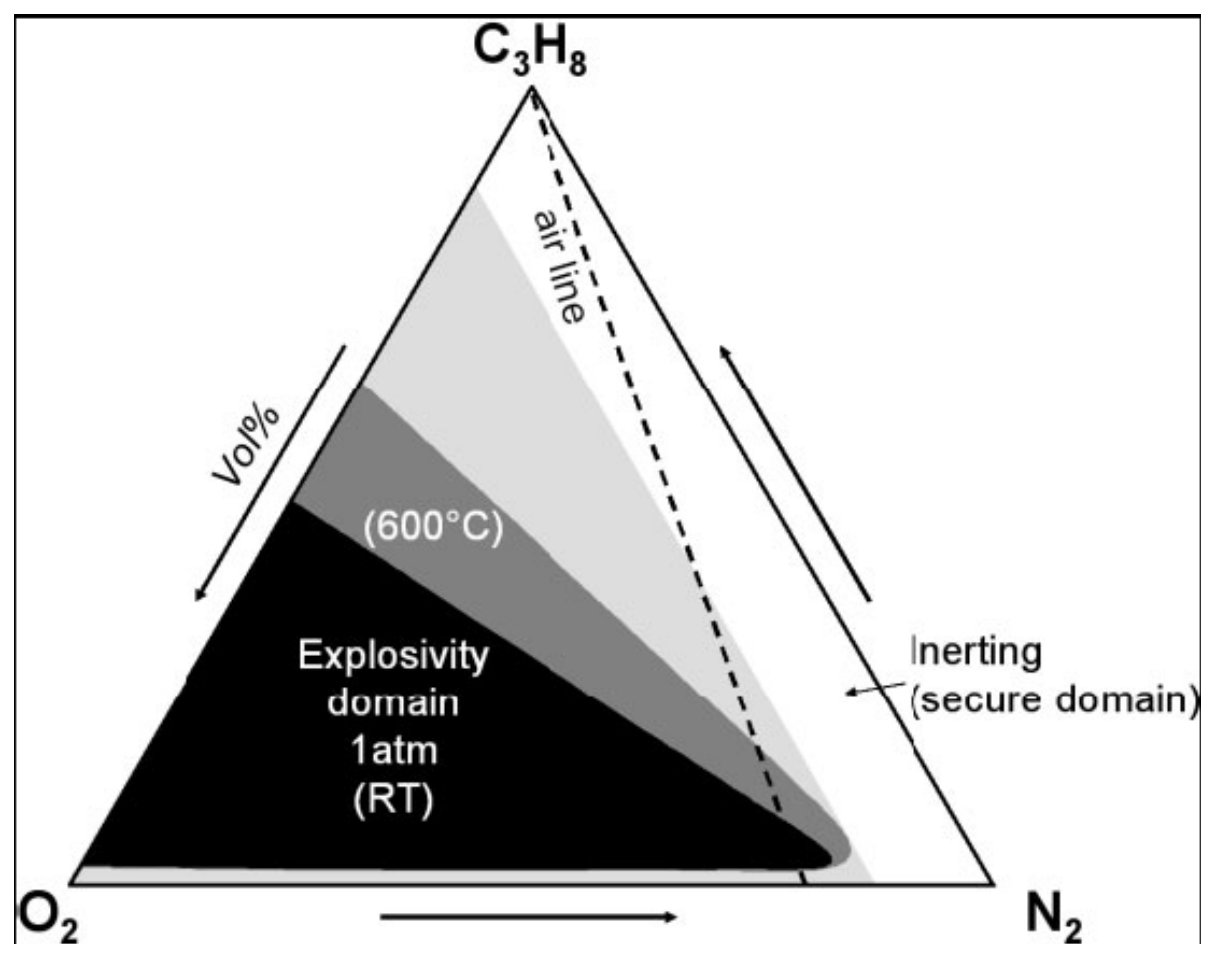

Figure 1: Schematic extrapolation of the Shapiro diagram for $\mathrm{C}_{3} \mathrm{H}_{8}-\mathrm{O}_{2}-\mathrm{N}_{2}$.

This device enables the study of a catalyst in a gas flow independently from the others, which are meanwhile submitted to an oxidising atmosphere (20:80 vol.- $\% \mathrm{O}_{2}: H e$ gas mixture, with a $50 \mathrm{~mL}$ min-1 total flow for each sample).

About $100 \mathrm{mg}$ of each sample have been submitted to this oxidising atmosphere at $400{ }^{\circ} \mathrm{C}$ prior to catalytic measurements, which were performed under a $3 \mathrm{~L} \mathrm{~h}$-1 total flow of 1.8 vol.- $\%$ propane in the previous oxidising atmosphere. Measurements were carried out as follows. The catalysts activity was measured in a sequential way, one after each other, at $400{ }^{\circ} \mathrm{C}$. Measurements were duplicated: the first one 2 min after the test starts (time $t_{2}$ ), and the second one $12 \mathrm{~min}$ later (time $\mathrm{t}_{14}$ ). Meanwhile, the other catalysts were exposed to 'air' flow. Thereby, all measurements were performed on fresh/regenerated catalysts, and problems due to activity measurements at different times could be avoided. After all reactors being studied, they were heated up under 'air' flow to the next temperature (450, 500, 550 and $\left.600{ }^{\circ} \mathrm{C}\right)$. A Ni sample and an empty reactor were used as reference catalyst and blank test, respectively.

\section{Conductivity in dilute hydrogen}

The total conductivity under dilute hydrogen of four samples of the La2(Mo2 - yWy)O9 series $(\mathrm{y}=0,0.5,1.0,1.4)$ was studied by impedance spectroscopy measurements. The first series of measurements was carried out at $608{ }^{\circ} \mathrm{C}$, first in air then in argon and finally in a $10 \% \mathrm{H} 2-$ $90 \% \mathrm{Ar}$ mixture for $24 \mathrm{~h}$. In air and argon, the resistivity remained stable for all samples, and the measured values (R0) were used as reference for further measurements in dilute hydrogen. Figure 2 shows the evolution with time of the relative resistivity $R / R_{0}$ for the four samples. The resistivity of the sample with highest $\mathrm{W}$ content $(\mathrm{y}=1.4)$ remains practically unchanged from Ar to H2:Ar mixture, whereas those of samples with lower W content decrease significantly in the first $5 \mathrm{~h}$. After about $10 \mathrm{~h}$, the resistance seems to stabilise, suggesting that thermodynamic equilibrium could have been reached. The lower the tungsten content is, the lower is the stabilised resistivity, therefore confirming that tungsten acts as a 
barrier against reduction, as previously evidenced [4]. Current measurements cannot differentiate between the ionic and electronic parts of conductivity. However, the thermal evolution of total conductivity under dilute hydrogen, recorded while cooling down from $608^{\circ} \mathrm{C}$, can give some hints about it (see Figure $3 \mathrm{a}$ ).

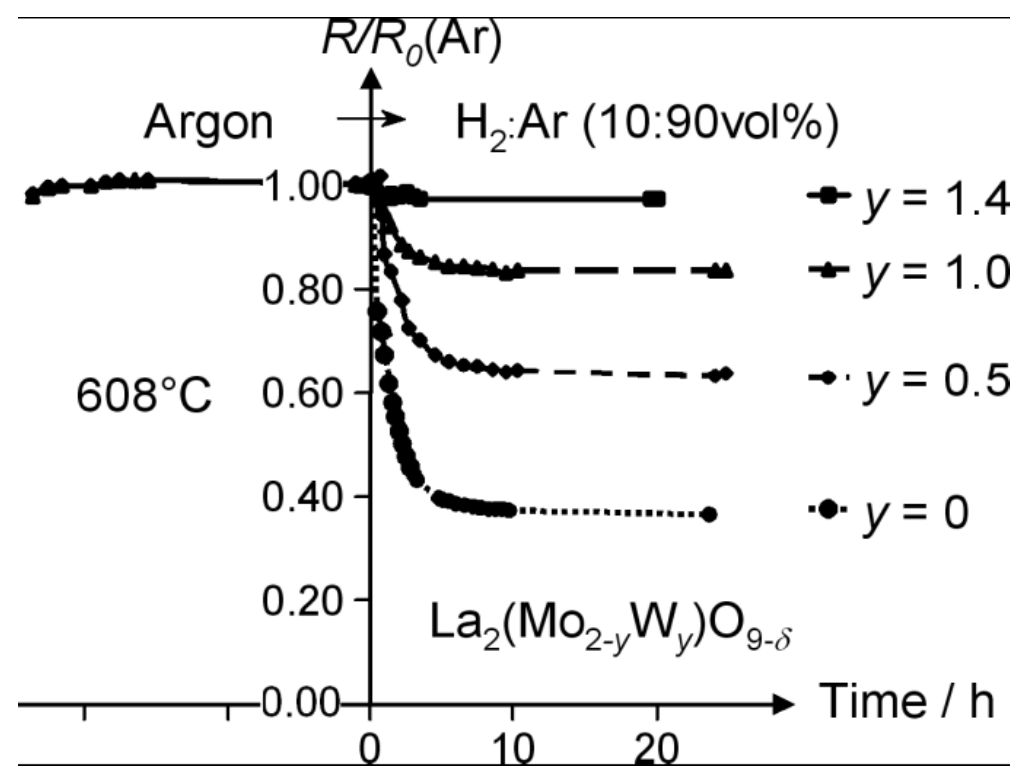

Figure 2: Time dependence of $\mathrm{La}_{2}\left(\mathrm{Mo}_{2}\right.$ - yWy)Og relative resistivity at $608^{\circ} \mathrm{C}$ under dilute hydrogen.

Figure 3 shows clearly that the total conductivity and activation energy measured on the oxidised phases while heating up in air, and on the reduced phases while cooling down in dilute hydrogen, are very different for the lowest $\mathrm{W}$ contents, where a huge increase in conductivity and a decrease in activation energy are observed. Here again, the lower the W content, the more pronounced is the effect (see Figure 3b). These results are in agreement with previous ones observed on Y/W doubly substituted LAMOX compounds [3]. Extra oxygen vacancies due to partial reduction could explain a slight increase in ionic mobility, but cannot justify alone a difference of several orders of magnitude in conductivity at low temperature. This, together with the lower activation energy, is more consistent with the appearance of electronic conductivity due to the occurrence of mixed valent molybdenum. In order to check the sample stability during the previous conductivity study in dilute hydrogen, we have performed room temperature X-ray diffraction measurements on the most sensitive pellet (La2Mo2O9) before and after the conductivity measurements. Figure 4 shows that the LAMOX structure is kept during the thermal treatment at $608{ }^{\circ} \mathrm{C}$ under dilute hydrogen, attesting that it can withstand partial reduction under these conditions without decomposing. However, long-term stability remains to be checked.

\section{Stability and Catalytic Activity in Propane:air}

\section{IV.1. Stability}

The main purpose of this stability study was to test whether LAMOX compounds of the tungsten series $\mathrm{La}_{2}\left(\mathrm{Mo}_{2}-\mathrm{yWy}_{2} \mathrm{O}_{9}\right.$ can be stable as electrolytes in a single chamber SOFC propane:air atmosphere at working temperature (around $600-700{ }^{\circ} \mathrm{C}$ ), and whether reduced LAMOX compounds without tungsten can be stable as electrodes in the same conditions. The conditions for and main results of the study are reported in Table 1.

The most reducible compound of the tungsten series, $y=0.25$, was not reduced in the propane:air mixture after $68 \mathrm{~h}$ at $700{ }^{\circ} \mathrm{C}$. The powder remained white and the XRD pattern showed a cubic LAMOX type structure. Besides, condensation of a clear, water-like liquid was observed in the furnace tube and exit bubbler.

As stated in the Experimental Section, the effect of nitrogen inerting and water vapour (in order to mimic a fuel cell water production) was tested. When both elements are present in 
the gas mixture, their effect on the LAMOX phase stability is significant, specially at $700{ }^{\circ} \mathrm{C}$ and whatever the $\mathrm{W}$ content ( $\mathrm{y}=0.25$ or 1.0 ); both samples become black and reduced to a major W-containing La7Mo7O30 type phase [10] (from XRD). In addition to reduction, side effects are observed such as coking (cold parts of furnace wall covered with soot), and condensation of a yellow viscous liquid. At $600{ }^{\circ} \mathrm{C}$, the same side effects are observed, but the $\mathrm{y}=0.25$ powder remained white and LAMOX type from XRD. One can wonder whether reduction at $700{ }^{\circ} \mathrm{C}$ is a direct effect of the gas mixture, or a side effect due to reaction with carbon after coking.

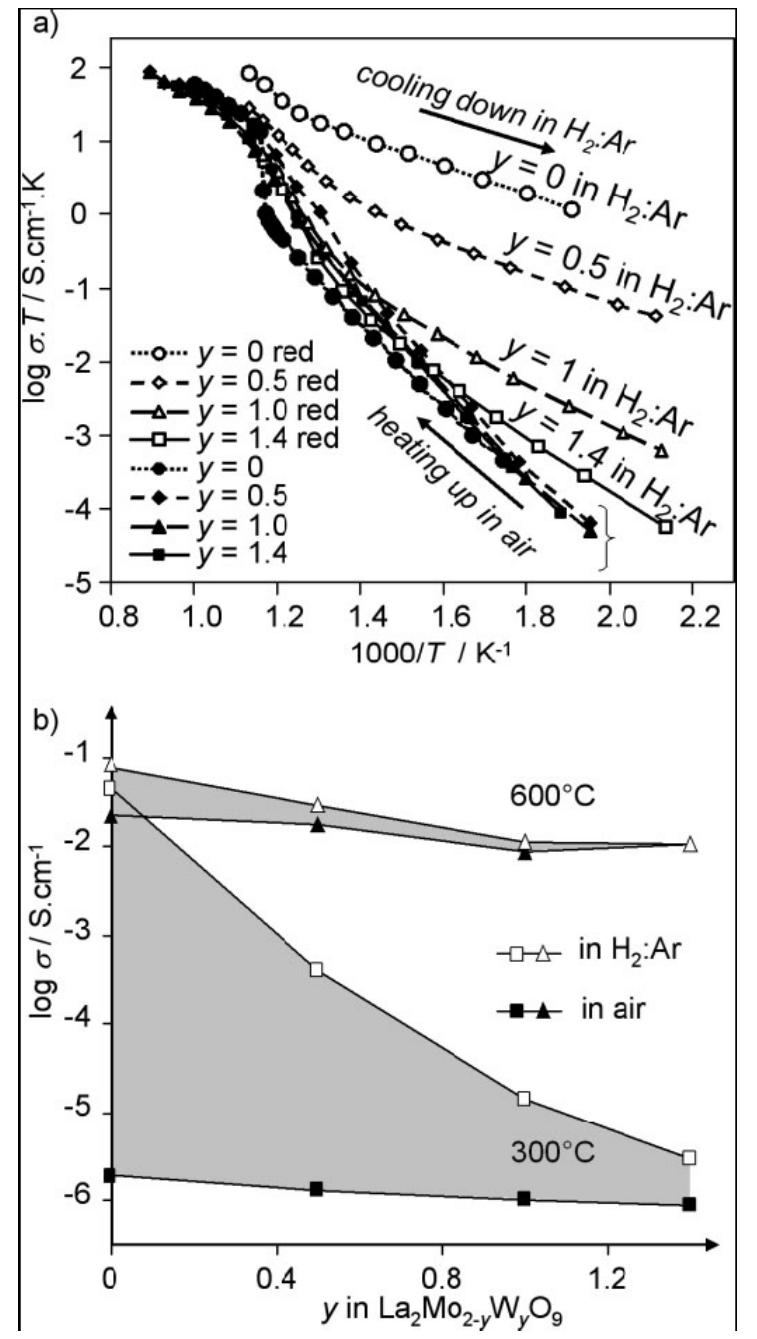

Figure 3: (a) Conductivity curves of La2(Mo2 - yWy)Og in air (heating up, close symbols) and in diluted hydrogen (cooling down, open symbols). (b) Total conductivity at 300 and $600{ }^{\circ} \mathrm{C}$ in air and in diluted hydrogen, as a function of tungsten amount. In first approximation, grey areas are assumed to roughly represent electronic contributions.

In order to check the importance of water in the above effects, a series of tests have been made with nitrogen inerting without water vapour (see Table 1). At $600{ }^{\circ} \mathrm{C}$ for 3 days, for all four sample tested, coking has disappeared. It seems, therefore, due to the presence of water. Correlatively, the powders remain LAMOX type, as controlled by XRD. One of the samples tested was $\mathrm{La}_{7} \mathrm{Mo}_{7} \mathrm{O}_{30}$, a partially reduced form of $\mathrm{La}_{2} \mathrm{Mo}_{2} \mathrm{O}_{9}$ with different structure [10], which appears to re-oxidise to $\mathrm{La}_{2} \mathrm{Mo}_{2} \mathrm{O}_{9}$ in the dry inerted propane: air gas mixture. 


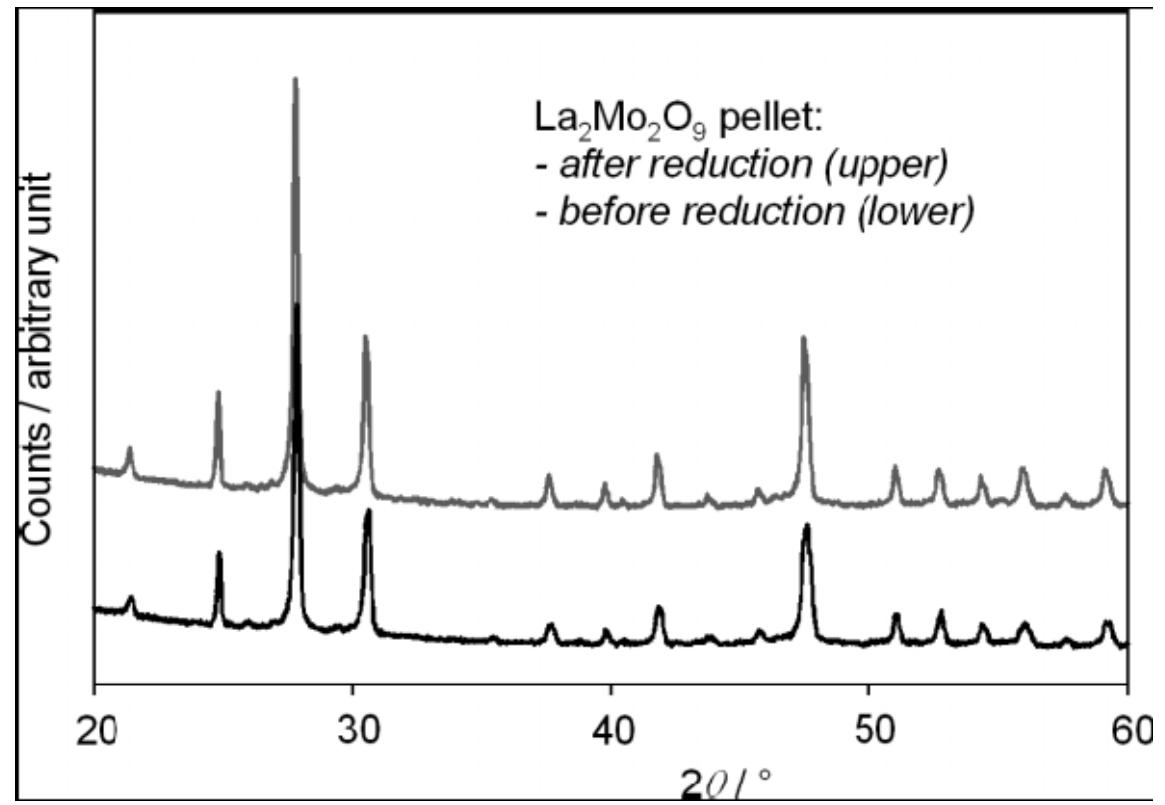

Figure 4: Room temperature X-ray diffraction patterns of the $\mathrm{La}_{2} \mathrm{Mo}_{2} \mathrm{O} 9$ pellet before and after the conductivity measurements under dilute hydrogen (after polishing the Pt electrode layer).

Table 1: Conditions for the stability measurements of LAMOX powders in propane: air mixtures and final products.

\begin{tabular}{|c|c|c|c|c|c|}
\hline Initial Compounds & Gas mixture & Flow (L/h) & $\mathrm{T}\left({ }^{\circ} \mathrm{C}\right)$ & $\mathrm{T}(\mathrm{h})$ & Products \\
\hline $\mathrm{La}_{2}\left(\mathrm{Mo}_{1.75} \mathrm{~W}_{0.25}\right) \mathrm{O}_{9}$ & $\mathrm{O}_{9} \mathrm{C}_{3} \mathrm{H}_{8}$ :air & $0.8: 4.2$ & 700 & 24 & White LAMOX \\
\hline $\mathrm{La}_{2}\left(\mathrm{Mo}_{1.75} \mathrm{~W}_{0.25}\right) \mathrm{O}_{9}$ & $\mathrm{O}_{9} \mathrm{C}_{3} \mathrm{H}_{8}$ :air & $0.8: 4.2$ & 700 & 68 & White LAMOX \\
\hline $\mathrm{La}_{2}\left(\mathrm{Mo}_{1.75} \mathrm{~W}_{0.25}\right) \mathrm{O}_{9}$ & $\begin{array}{l}\mathrm{C}_{3} \mathrm{H}_{8}: \text { air: } \mathrm{N}_{2}+ \\
\mathrm{H}_{2} \mathrm{O}\end{array}$ & $\begin{array}{l}0.8: 4.2: 5 \\
\text { + bubbles }\end{array}$ & 700 & 42 & Black La_Mo- $\mathrm{O}_{30}$ type \\
\hline $\mathrm{La}_{2}\left(\mathrm{MoW} \mathrm{O}_{9}\right.$ & $\begin{array}{l}\mathrm{C}_{3} \mathrm{H}_{8}: \text { air: } \mathrm{N}_{2}+ \\
\mathrm{H}_{2} \mathrm{O}\end{array}$ & $\begin{array}{l}0.8: 4.2: 5 \\
\text { + bubbles }\end{array}$ & 700 & 72 & Black $\mathrm{La}_{7} \mathrm{Mo}_{7} \mathrm{O}_{30}$ type \\
\hline $\mathrm{La}_{2}\left(\mathrm{Mo}_{1.75} \mathrm{~W}_{0.25}\right) \mathrm{O}_{9}$ & $\begin{array}{l}\mathrm{C}_{3} \mathrm{H}_{8}: \text { air: } \mathrm{N}_{2}+ \\
\mathrm{H}_{2} \mathrm{O}\end{array}$ & $\begin{array}{l}0.8: 4.2: 5 \\
\text { + bubbles }\end{array}$ & 600 & 42 & White LAMOX \\
\hline $\mathrm{La}_{2}(\mathrm{MoW}) \mathrm{O}_{9}$ & $\mathrm{C}_{3} \mathrm{H}_{8}:$ air: $\mathrm{N}_{2}$ & $0.8: 4.2: 5$ & 600 & 72 & White $\mathrm{La}_{2} \mathrm{MO}_{2} \mathrm{O}_{9}$ \\
\hline $\mathrm{La}_{7} \mathrm{Mo}_{7} \mathrm{O}_{30}$ & $\mathrm{C}_{3} \mathrm{H}_{8}:$ air: $\mathrm{N}_{2}$ & $0.8: 4.2: 5$ & 600 & 72 & White $\mathrm{La}_{2} \mathrm{MO}_{2} \mathrm{O}_{9}$ \\
\hline $\mathrm{La}_{2}\left(\mathrm{Mo}_{1.9} \mathrm{~V}_{0.1}\right) \mathrm{O}_{8.95}$ & $\mathrm{C}_{3} \mathrm{H}_{8}:$ air: $\mathrm{N}_{2}$ & $0.8: 4.2: 5$ & 600 & 72 & Grey LAMOX \\
\hline $\mathrm{La}_{2}\left(\mathrm{Mo}_{1.75} \mathrm{~W}_{0.25}\right) \mathrm{O}_{9}$ & $\mathrm{C}_{3} \mathrm{H}_{8}:$ air: $\mathrm{N}_{2}$ & $0.8: 4.2: 5$ & 600 & 72 & Grey LAMOX \\
\hline
\end{tabular}

\section{IV.2. Catalytic Activity}

As a preliminary remark, a few LAMOX compounds showed an initial peak of catalytic activity at time $t_{2}$ ( 2 min after start), followed by a decrease at time $t_{14}$ (14 min after start). Such a transient phenomenon will be discussed below.

The catalytic activity for propane oxidation of the Ni and LAMOX compounds were recorded at different temperatures in stationary conditions at time $t_{14}$. The results are reported in Figure 5. The blank test (with no sample) showed that no reaction takes place in the gas phase even at high temperature, thus discarding gas phase contribution. Not surprisingly, the Ni sample showed the highest catalytic activity at each temperature, with $98 \%$ of propane conversion at $600{ }^{\circ} \mathrm{C}$. $\mathrm{La}_{2} \mathrm{Mo}_{2} \mathrm{O}_{9}$, both in its monoclinic $\left(\mathrm{T}<580{ }^{\circ} \mathrm{C}\right)$ and in its cubic $\left(\mathrm{T}>580^{\circ} \mathrm{C}\right)$ crystalline forms [18], appears to be by far the most active of all LAMOX compounds at each temperature, with $79 \%$ of propane conversion at $600{ }^{\circ} \mathrm{C}$. All othertested substituted LAMOX compounds show a much lower activity (less than $15 \%$ at any temperature). In all cases, the almost exclusive formation of $\mathrm{CO}_{2}$ and the presence of water traces not totally condensed in the Peltier cooler are characteristic of a full oxidation. When notlacking, only minimal traces of $\mathrm{CO}, \mathrm{C}_{3} \mathrm{H}_{6}$ or derivatives could be identified (see Table 2) 


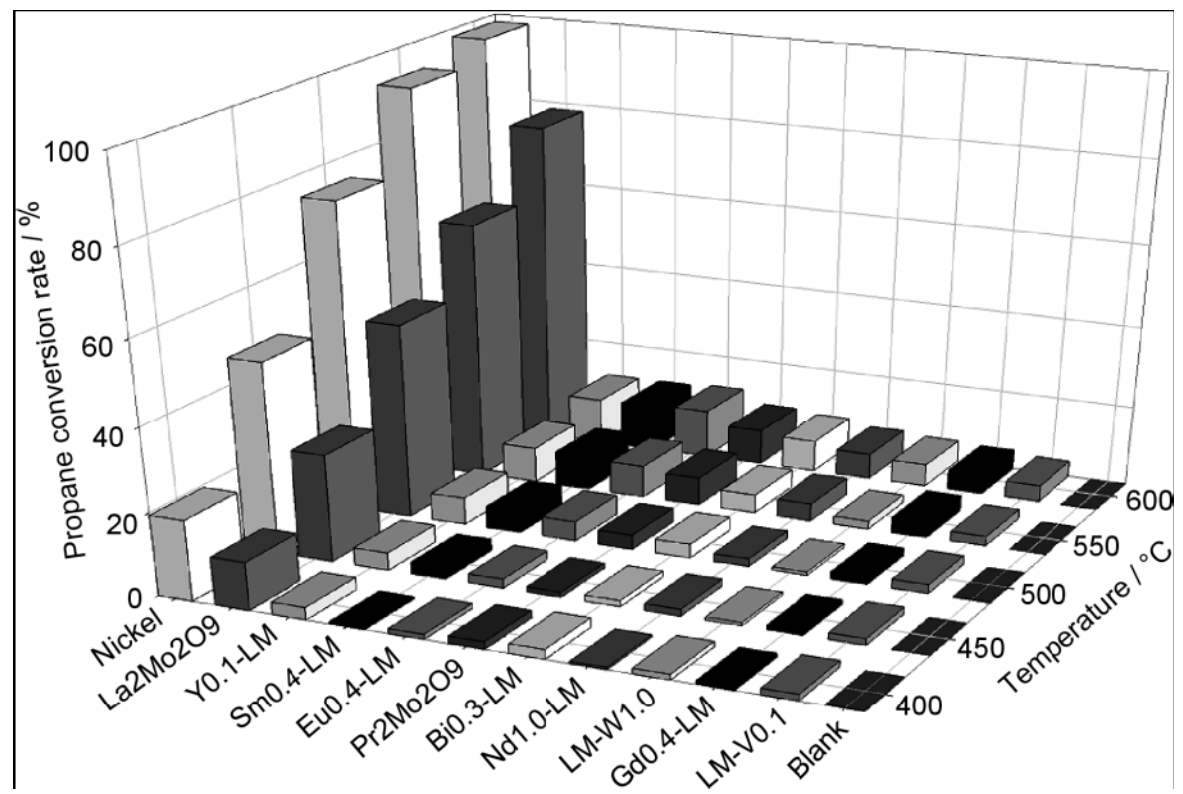

Figure 5: Conversion rates of propane (full oxidation) at different temperatures on a series of LAMOX oxide-ion conductors, compared to that of nickel (measurements performed in stationary conditions after $14 \mathrm{~min}$ of propane: 'air' exposure). Codes for composition : $\mathrm{Ax}-\mathrm{LM}=\mathrm{La}_{2}-\mathrm{xAxMo}_{2} \mathrm{O}_{9}-\mathrm{d}$, LM-By $=\mathrm{La}_{2} \mathrm{Mo}_{2}-\mathrm{yByO}_{9}-\mathrm{d}$.

To illustrate the transient phenomenon mentioned above, the conversion rate of propane on ( $\left.\mathrm{La}_{1.9} \mathrm{Y}_{0.1}\right) \mathrm{Mo}_{2} \mathrm{O}_{9}$ is shown in Figure 6a. It is systematically higher than or equal to $20 \%$ at the initial measurement time $t_{2}$, but drops dramatically at time $t_{14}$. Besides, the propane conversion rate at time $t_{2}$ is characterised by a carbon balance lower than $100 \%$, which accounts for a carbon formation in the reactor (Figure $6 \mathrm{~b}$ and Table 2). At time $\mathrm{t}_{14}$, the carbon balance catches up with $100 \%$, but in this case the carbon retention effect is probably hidden by the low conversion rate of propane, as can be seen in Table 2. Note that, however, due to this low conversion rate of propane, the accuracy of selectivity measurements is probably rather lower here. After heating under 'air' flow, the sample activity is recovered. $\mathrm{La}_{2} \mathrm{Mo}_{2} \mathrm{O}_{9}$ is also subject to deactivation at low temperature (Figure 6a), whereas it maintains its activity at higher temperature.

Other compounds such as $\operatorname{Pr}_{2} \mathrm{Mo}_{2} \mathrm{O}_{9}$ or $\mathrm{La}_{2}\left(\mathrm{Mo}_{1.9} \mathrm{~V}_{0.1}\right) \mathrm{O}_{8.95}$ exhibit a higher activity at time $\mathrm{t}_{2}$ than at time $t_{14}$, which is accompanied with a carbon formation (data not shown). But in their cases, this phenomenon is observed at one temperature only, which could suggest that their deactivation is irreversible. It is however difficult to draw firm conclusions from data that could correspond to measurement artefacts.

All LAMOX compounds tested in methane:'air' atmosphere showed much lower activity than in propane: 'air' at the same temperatures. $\mathrm{La}_{2} \mathrm{Mo}_{2} \mathrm{O}_{9}$ was still the most active catalyst, but with only $8 \%$ conversion rate of methane at $600{ }^{\circ} \mathrm{C}$.

This result is in agreement with the usual observation that 'methane is the most difficult hydrocarbon to oxidise, because $\mathrm{CH}_{4}$ contains the strongest $\mathrm{C}-\mathrm{H}$ bond of all alkanes' (see Ref. [19] and references therein)

\section{Discussion and Conclusion}

The above study shows that LAMOX compounds, as a function of their composition, could be used as various components in a SOFC core depending on the cell configuration and operating temperature (see Table 3).

For dual-chamber configuration, conductivity measurements under dilute hydrogen on the $\mathrm{La}_{2}\left(\mathrm{Mo}_{2}-\mathrm{yWy}\right) \mathrm{O}_{9}$ series suggest that the composition with highest tungsten content $(\mathrm{y}=1.4)$, provided that its electronic transport number is low enough (to be checked), could be used as electrolyte at intermediate temperature (below $600{ }^{\circ} \mathrm{C}$ ). It would necessitate a relatively thin electrolytic membrane (micro-SOFC geometry) in order to lower the ohmic losses. On the contrary, those LAMOX compounds with low tungsten content seem more suited as anode 
materials when $\mathrm{H}_{2}$ is used as fuel, since their partial reduction make them mixed ionicelectronic conductors.
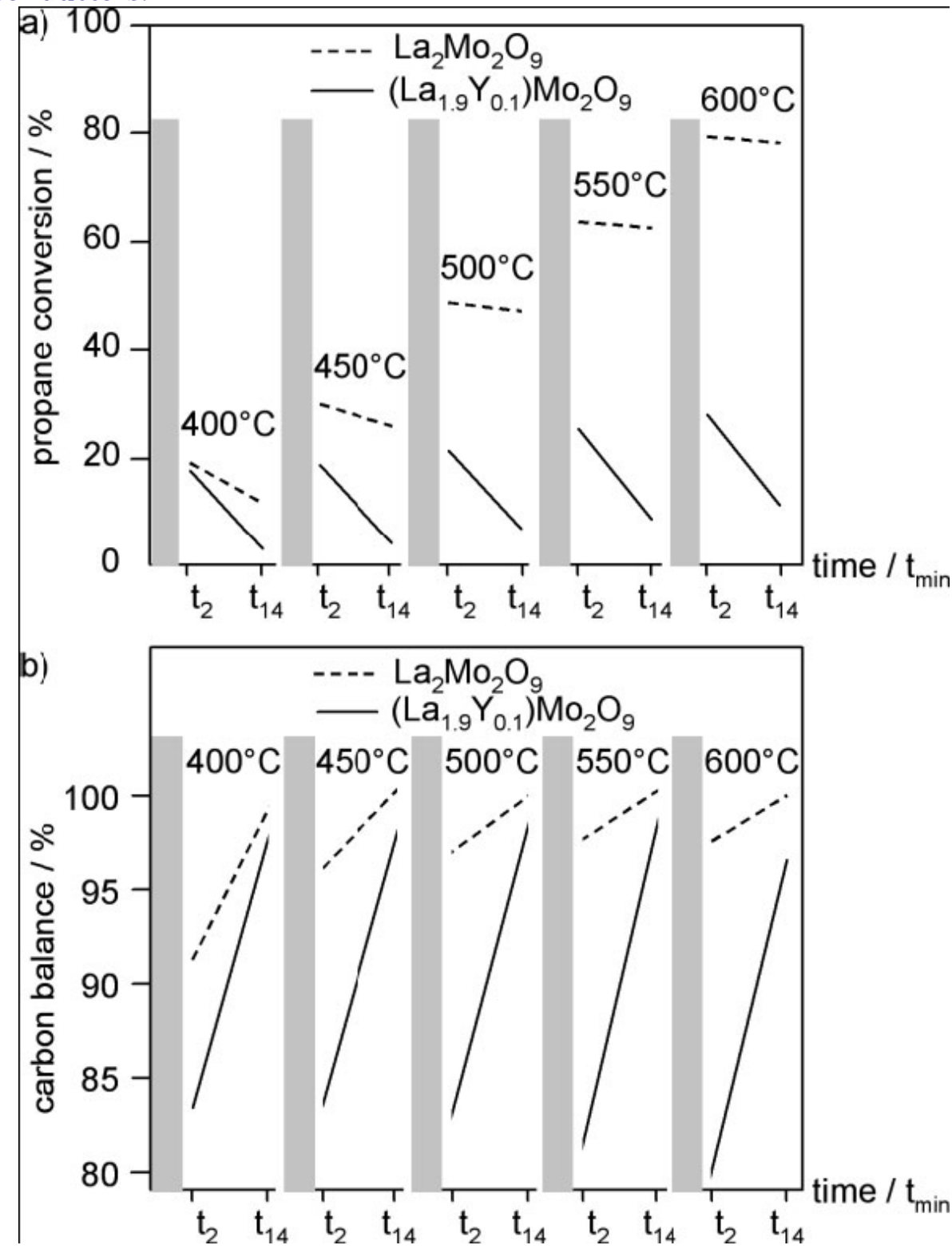

Figure 6: Propane conversion rate (a) and carbon balance (b) during the catalytic activity measurements of $\mathrm{La}_{2} \mathrm{Mo}_{2} \mathrm{O}_{9}$ and $\left(\mathrm{La}_{1.9} \mathrm{Y}_{0.1}\right)_{\mathrm{Mo}} \mathrm{O} 9$. Carbon balance corresponds to the ratio between carbon amount detected in the outflow gas mixture and carbon amount in the feeding gas mixture. Grey areas represent 'air' feeding periods, measurements being made in propane: 'air' mixture at time $\mathrm{t}_{2}$ and $\mathrm{t}_{14}$.

More work is however needed to improve their electronic conductivity by finding the most appropriate compositions and reduction temperatures. In any case, the grain size and sample shaping are likely to affect the materials properties and thermal stability [20].

In single-chamber configuration, the tested LAMOX compounds appear to be stable as electrolyte (oxidised compounds) at $600-700{ }^{\circ} \mathrm{C}$ in a characteristic dry propane:air mixture, inerted or without nitrogen. It would preclude the use of reduced LAMOX compounds as anode materials in such environments, but we noticed that the presence of water in the gas mixture tends to favour LAMOX reduction. Since water vapour is not specially a reducing gas, a steam reforming (with gas shift) reaction probably takes place with propane and forms $\mathrm{H}_{2}$, which is a reducing agent. Since, in a SOFC device, water production is localised at the anodic side, further tests are needed in cell-type configuration in order to determine whether the water production in the cell is able to stabilise or not a reduced LAMOX phase at the anode. 
Table 2: Catalytic performances of $\mathrm{Ni}, \mathrm{La}_{2} \mathrm{Mo}_{2} \mathrm{O}_{9}$ and $\mathrm{La}_{1.9} \mathrm{Y}_{0.1} \mathrm{Mo}_{2} \mathrm{O}_{9}$ in 1.8:98.2 vol.\% propane: 'air' mixture at different temperatures and reaction advancement (selectivity of gas products as measured by gas chromatography, and undetected $\mathrm{C}$ as deduced from carbon balance in the gas phase). ${ }^{\mathrm{a}}$

\begin{tabular}{|c|c|c|c|c|c|c|c|c|c|c|c|c|c|}
\hline \multirow{3}{*}{ Compound } & \multirow{3}{*}{$\mathrm{T}\left({ }^{\circ} \mathrm{C}\right)$} & \multirow{2}{*}{\multicolumn{2}{|c|}{$\begin{array}{c}\text { Conversion } \\
\mathrm{O}_{2}(\%)\end{array}$}} & \multirow{2}{*}{\multicolumn{2}{|c|}{$\begin{array}{l}\text { Conversion } \\
\qquad \mathrm{C}_{3} \mathrm{H}_{8}(\%)\end{array}$}} & \multicolumn{8}{|c|}{ C selectivity (\%) } \\
\hline & & & & & & \multicolumn{2}{|c|}{$\mathrm{CO}_{2}$} & \multicolumn{2}{|c|}{$\mathrm{CO}$} & \multicolumn{2}{|c|}{$\mathrm{C}_{3} \mathrm{H}_{6}$} & \multicolumn{2}{|c|}{ Undetected C } \\
\hline & & $2^{\prime}$ & $14^{\prime}$ & 2 & $14^{\prime}$ & 2 & $14^{\prime}$ & 2 & $14^{\prime}$ & 2 & $14^{\prime}$ & 2 & $14^{\prime}$ \\
\hline \multirow[t]{5}{*}{$\mathrm{Ni}$} & 400 & 19 & 20 & 18 & 19 & 71 & 73 & 0 & 0 & 4 & 4 & 25 & 23 \\
\hline & 450 & 28 & 29 & 43 & 46 & 88 & 88 & 0 & 0 & 4 & 3 & 8 & 9 \\
\hline & 500 & 38 & 38 & 73 & 75 & 95 & 94 & 0 & 0 & 2 & 2 & 3 & 4 \\
\hline & 550 & 45 & 44 & 92 & 93 & 98 & 96 & 0 & 0 & 1 & 1 & 1 & 3 \\
\hline & 600 & 45 & 46 & 99 & 98 & 87 & 98 & 0 & 0 & 0 & 0 & 13 & 2 \\
\hline \multirow[t]{5}{*}{$\mathrm{La}_{2} \mathrm{Mo}_{2} \mathrm{O}_{9}$} & 400 & 15 & 14 & 19 & 12 & 54 & 95 & 0 & 0 & 0 & 1 & 46 & 4 \\
\hline & 450 & 21 & 21 & 30 & 26 & 86 & 99 & 0 & 0 & 1 & 1 & 13 & 0 \\
\hline & 500 & 27 & 27 & 49 & 47 & 93 & 99 & 0 & 0 & 1 & 1 & 6 & 0 \\
\hline & 550 & 32 & 32 & 64 & 62 & 95 & 99 & 0 & 0 & 1 & 1 & 4 & 0 \\
\hline & 600 & 37 & 37 & 80 & 78 & 96 & 99 & 0 & 0 & 1 & 1 & 3 & 0 \\
\hline \multirow{5}{*}{$\begin{array}{l}\mathrm{La}_{1.9} \mathrm{Y}_{0.1} \\
\mathrm{Mo}_{2} \mathrm{O}_{9}\end{array}$} & 400 & 13 & 13 & 18 & 3 & 6 & 38 & 0 & 0 & 0 & 0 & 94 & 62 \\
\hline & 450 & 14 & 14 & 19 & 4 & 11 & 61 & 0 & 0 & 0 & 0 & 89 & 39 \\
\hline & 500 & 15 & 15 & 21 & 7 & 19 & 77 & 0 & 0 & 0 & 1 & 81 & 22 \\
\hline & 550 & 16 & 16 & 25 & 9 & 24 & 82 & 0 & 0 & 1 & 4 & 75 & 14 \\
\hline & 600 & 16 & 15 & 28 & 11 & 24 & 57 & 0 & 1 & 3 & 11 & 73 & 31 \\
\hline
\end{tabular}

a) Other gas tested, either measured as traces or not detected: $\mathrm{CH}_{4}, \mathrm{i}-\mathrm{C}_{4} \mathrm{H}_{10}, \mathrm{i}-\mathrm{C}_{4} \mathrm{H}_{8}, \mathrm{C}_{2} \mathrm{H}_{4} \mathrm{O}$ (acetaldehyde), $\mathrm{C}_{3} \mathrm{H}_{4} \mathrm{O}$ (acrolein), $\mathrm{C}_{3} \mathrm{H}_{6} \mathrm{O}$ (acetone and propionaldehyde and allyl alcohol), $\mathrm{C}_{2} \mathrm{H}_{4} \mathrm{O}_{2}$ (acetic acid), $\mathrm{C}_{3} \mathrm{H}_{6} \mathrm{O}_{2}$ (propionic acid), $\mathrm{C}_{3} \mathrm{H}_{4} \mathrm{O}_{2}$ (acrylic acid).

b) $\mathrm{C}$ selectivity was calculated as the number of carbon atom moles in the given product divided by 3 times the number of moles of propane reacted.

The exalted catalytic activity of $\mathrm{La}_{2} \mathrm{Mo}_{2} \mathrm{O}_{9}$ for propane oxidation is clearly evidenced by this study. $\mathrm{La}_{2} \mathrm{Mo}_{2} \mathrm{O}_{9}$ is the most active of tested LAMOX compounds, with a conversion rate almost equal to that of nickel. Additional experiments in a less oxidising propane:air mixture, or better in a direct propane SOFC, should be undertaken to characterise the selectivity of $\mathrm{La}_{2} \mathrm{Mo}_{2} \mathrm{O}_{9}$ in order to evaluate the materials as anode in such devices. An alternative would be to design $\mathrm{Ni}-\mathrm{La}_{2} \mathrm{Mo}_{2} \mathrm{O}_{9}$ cermet since $\mathrm{La}_{2} \mathrm{Mo}_{2} \mathrm{O}_{9}$ is unreactive with nickel [21].

Table 3: Overview of possible use of LAMOX compounds in SOFC devices, as deduced from the current study

\begin{tabular}{|c|c|c|}
\hline SOFC & Dual chamber & Single chamber \\
\hline Electrolyte & $\begin{array}{l}\text { Micro-SOFC: high W content, low } T \\
\left(500^{\circ} \mathrm{C}\right) \text { Macro-SOFC: protective layer } \\
\text { necessary }\end{array}$ & $\begin{array}{l}\text { Electrolyte stable in dry } \\
\text { propane:air atmosphere }\end{array}$ \\
\hline Anode & $\begin{array}{l}\text { Low W content (composition to be } \\
\text { optimised as a function of operating } \\
\text { temperature) }\end{array}$ & $\begin{array}{l}\text { Reduction favoured by water } \\
\text { produced at anode }\end{array}$ \\
\hline Anode catalyst & $\begin{array}{l}\mathrm{La}_{2} \mathrm{Mo}_{2} \mathrm{O}_{9} \text { good oxidation catalyst of } \\
\text { propane (to be tested in direct } \\
\text { hydrocarbon SOFC) }\end{array}$ & $\begin{array}{l}\mathrm{La}_{2} \mathrm{Mo}_{2} \mathrm{O}_{9} \text { good oxidation } \\
\text { catalyst of propane (to be } \\
\text { tested in SCFC) }\end{array}$ \\
\hline
\end{tabular}

The impact of substitution on the LAMOX catalytic activities is still unclear and should be subject to further investigations. However, we can give some assumptions. Like VI-B transition metal, Mo oxides and mixed oxides are well known for their capacities for hydrocarbon activation [22]. Thus, we can anticipate that chemical substitutions could lead, 
depending on their nature, to more or less surface depreciation of Mo content, thus reducing or even preventing the catalytic activity. However, a strong interaction with some substituting elements, which may reduce the acid feature of Mo oxides, cannot be ruled out. Whatever its form, the carbon formation observed in LAMOX compounds such as ( $\left.\mathrm{La}_{1.9} \mathrm{Y}_{0.1}\right) \mathrm{Mo}_{2} \mathrm{O}_{9}$, concomitantly with their deactivation, is also likely to block the access to active sites. Complementary studies are necessary to elucidate these phenomena.

Finally, the results presented in this paper suggest that LAMOX materials, due to their versatility (see Table 3), might be suited to specific SOFC designs with composition gradients, which would minimise reactivity between the cell components and therefore ageing problems.

\section{Acknowledgements}

The authors thank Arnold Desmartin-Chomel IRCELYON) for his help with catalytic measurements. ADEME (the French Agency for Environment and Energy Mastering) and Région Pays de la Loire are acknowledged for J . J acquens'PhD thesis grant, as well as ECOSSUD program for its support to this work (project A07E03). The authors deplore the lack of any support by French ANR (Research National Agency) despite several proposals.

This paper was presented at the Fundamental and Developments of Fuel Cells 2008 Conference (FDFC08) held in Nancy, France, on 10- 12 December 2008.

\section{References}

[1] P. Lacorre, F. Goutenoire, O. Bohnke, R. Retoux, Y. Laligant, Nature 2000, 404, 856.

[2] F. Goutenoire, O. Isnard, E. Suard, O. Bohnke, Y. Laligant, R. Retoux, P. Lacorre, J. Mater. Chem. 2001, 11, 119.

[3] P. Pinet, J. Fouletier, S. Georges, Mater. Res. Bull. 2007, 42, 935.

[4] S. Georges, F. Goutenoire, Y. Laligant, P. Lacorre, J. Mater. Chem. 2003, 13, 2317.

[5] D. Marrero-Lopez, J. Canales-Vazquez, J . C. Ruiz-Morales, J. T. S. Irvine, R. Nunez, Electrochimica Acta 2005, 50, 4385.

[6] W. X. Kuang, Y. N. Fan, J. H. Qiu, Y. Chen, J. Mater. Chem. 1998, 8, 19.

[7] S. McIntosh, R. J . Gorte, Chem. Rev. 2004, 104, 4845.

[8] Z. L. Zhan, J. Liu, S. A. Barnett, Appl. Catal. A-Gen. 2004, 262, 255.

[9] P. K. Cheekatamarla, C. M. Finnerty, J. Cai, Int. J. Hydrogen Energy 2008, 33, 1853.

[10] F. Goutenoire, R. Retoux, E. Suard, P. Lacorre, J. Solid State Chem. 1999, 142, 228.

[11] T. Hibino, A. Hashimoto, T. Inoue, J. Tokuno, S. Yoshida, M. Sano, Science 2000, 288, 2031.

[12] Z. P. Shao, S. M. Haile, J . Ahn, P. D. Ronney, Z. L. Zhan, S. A. Barnett, Nature 2005, 435, 795.

[13] J . M. Petit, J . L. Poyard, Rapport INRS 2004, Brochure ED 911.

[14] A. Bentaib, J. Vendel, Rapport Scientifique et Technique IRSN 2006, Recherche sur les accidents.

[15] I. C. Stefan, C. P. Jacobson, S. J. Visco, L. C. De J onghe, Electrochem. Solid State Lett. 2004, 7, A198.

[16] M. Yano, A. Tomita, M. Sano, T. Hibino, Solid State Ionics 2007, 177, 3351.

[17] G. Morra, A. Desmartin-Chomel, C. Daniel, U. Ravon, D. Farrusseng, R. Cowan, A. Krusche, C. Mirodatos, Chem. Eng. J. 2008, 138, 379.

[18] F. Goutenoire, O. Isnard, R. Retoux, P. Lacorre, Chem.Mater. 2000, 12, 2575.

[19] O. Demoulin, B. Le Clef, M. Navez, P. Ruiz, Appl. Catal.A-Gen. 2008, 344, 1.

[20] A. Selmi, G. Corbel, S. Kojikian, V. Voronkova, E. Kharitonova, P. Lacorre, Eur. J. Inorg. Chem. 2008, 1813.

[21] G. Corbel, P. Lacorre, J. Solid State Chem. 2006, 179, 1339.

[22] V. D. Sokolovskii, Catal. Rev. Sci. Eng. 1990, 32, 1. 